\title{
Utilisation of Agrowaste Xylan for the Production of Industrially Important Enzyme Xylanase from Aquatic Streptomyces sp. and Potential Role of Xylanase in Deinking of Newsprint
}

\author{
Emilda Rosmine*, Neethu Changan Edassery Sainjan, Reshma Silvester \\ and Saramma Aikkarakunnath Varghese
}

\begin{abstract}
Department of Marine Biology, Microbiology and Biochemistry, School of Marine Sciences, CUSAT, Kerala, India
\end{abstract}

*Corresponding author

\begin{abstract}
A B S T R A C T
Keywords

Xylanase,

Streptomyces,

Fermentation,

Optimisation,

Agrowastes,

Deinking

Article Info

Accepted:

15 December 2018

Available Online:

10 January 2019

Xylanase is an industrially significant enzyme and its production from pure xylan is expensive. The objective of the current study is to utilise sustainable cost effective substrates -coconut oil cake, corn cob, sugarcane bagasse and water hyacinth, for xylanase production. Streptomyces sp. ER1 isolated from the sediments of Cochin estuary was used for xylanase production. The cultural and nutritional conditions for higher xylanase production using the four substrates were optimised using one factor at a time method. Data were analysed by one way ANOVA. The maximum xylanase yield was observed for sugarcane bagasse $(10533.33 \mathrm{U} / \mathrm{mL})$, corn cob $(7880.9 \mathrm{U} / \mathrm{mL})$ followed by, coconut oil cake $(7680 \mathrm{U} / \mathrm{mL})$ and water hyacinth $(6930 \mathrm{U} / \mathrm{mL})$ in submerged fermentation. Optimisation studies revealed that optimum fermentation and nutritional factors varied with the substrate. The crude xylanase was vastly effective in deinking of the newspaper at elevated temperature. This study proved that utilising agrowastes provides cost effective and eco-friendly method for xylanase production on large scale. Thus it is an alternative approach to reducing environmental pollution caused due to dumping agro waste. No studies on xylanaolytic activity of actinomycetes from Cochin estuary has been done so far.
\end{abstract}

\section{Introduction}

Xylanases (EC 3.2.1.8) are a class of inducible enzymes, liable for the complete hydrolysis of xylan into simpler compounds, consisting mainly of xylose (Gupta and Kar, 2009). Above few years, global market of xylanase is extended swiftly due to its greater potential for industrial use, mainly in the biotechnological applications in the industry of pulp and paper, baking, textiles, animals feed, biofuels, food and beverages (Ho and Lau, 2014). The marine actinomycetes found in a wide range of aquatic environments, like estuary and mangroves, are well-known to produce chemically diverse compounds with a broad range of biological activities that have commercial applications (Gulve and 
Deshmukh, 2011). The marine environment regards with the isolation of indigenous Streptomyces as these microbes gained special importance because of their capability to produce novel secondary metabolites or enzymes with a wide range of biological activities (Gulve and Deshmukh, 2011; Solanki et al., 2008). Nevertheless, the expenditure of xylan dependent xylanase production confines its use in industrial applications.

Agricultural by-products containing cellulose, hemicelluloses and lignin could provide as effective and inexpensive sources for xylanase production (Lam, 2006). The accessibility of agricultural waste in India is about 625 million tonnes annually including groundnut cake, rice bran, rice straw, wheat bran, sugarcane bagasse, etc. (Techappun et al., 2003). The pollution problems linked with agro-industrial wastes, like, shortage of places for its disposal, pricey treatment options and enhanced need to save valuable resources have put on to encourage the utilisation and bioconversion of waste into high industrial products (Bhosale et al., 2011). The use of pest plants and cheap agricultural and foodprocessing by-products is highly favoured so as to develop the commercial viability of bioprocess technology (Sivaramakrishnan and Gangadharan, 2009).

So far, no wide studies have been done in the aquatic actinomycetes and their ability to produce industrial enzymes in Cochin estuary. The estuarine sediment harbours many potent microorganisms, producing xylanase. The mangrove ecosystem associated with Cochin estuary is ideal for growing different microorganisms; due to progressing impact of tides. This, it is crucial that a broad spectrum activity of actinomycetes from hitherto unexplored habitats be considered as sources of xylanase. The current study is an effort to produce xylanase from agrowastes, like coconut oil cake, corn cob, sugarcane bagasse and water hyacinth (pest plant) using Streptomyces sp. ER1 isolated from Cochin estuarine sediment. Numerous reports suggest that apart from the nature of substrate, physical and nutritional parameters also greatly affect the production of xylanase on agricultural waste (Barrios- Gonzalez et al., 1993). Thus during the present study - the effect of physical and nutritional parameters on xylanase production by Streptomyces sp. ER1 on different substrates was investigated. The study also focuses on the application of enzyme on newspaper deinking.

\section{Materials and Methods}

\section{Microorganism and inoculum preparation}

Actinomycete cultures were isolated from sediment samples of Cochin estuary (Rosmine and Saramma, 2016). Isolate ER1 with good xylanase activity was selected and confirmed its identification as Streptomyces sp. ER1 by $16 \mathrm{~S}$ rRNA gene amplification. The sequence was deposited in the Genbank with an accession number KY449279. The selected actinomycete was subcultured in nutrient agar slants containing $1 \%$ beech wood xylan $(\mathrm{pH}$ 7.0) and incubated at $35^{\circ} \mathrm{C}$ for five days.

\section{Collection and preparation of substrates}

The substrates corn cob, coconut oil cake and sugarcane bagasse were bought from a local market in Ernakulam, Kerala, India, to study about xylanase production using solid state and submerged fermentation. Eichhornia crassipes (water hyacinth) was collected from Vembanad Lake. All the substrates were washed with distilled water and then dried out in the oven. Sugarcane bagasse, corn cob and water hyacinth were cut into small pieces (5 $\mathrm{mm}$ size) and dried in the hot oven at $80^{\circ} \mathrm{C}$ for $1 \mathrm{~h}$. Coconut oil cake was then powdered using an electrical grinder and used for xylanase production. 


\section{Pre-treatment of substrates}

Pre-treatment of substrates was following a modified method of Ali et al., (1991). The prepared substrates were autoclaved for 1 hour with $5 \%(\mathrm{w} / \mathrm{v}) \mathrm{NaOH}(20 \mathrm{~mL}$ per gram of substrate) in separate conical flasks for delignification and filtered through muslin cloth. They were then washed with water, neutralized with $1 \mathrm{M} \mathrm{HCl}$. and dried at $70^{\circ} \mathrm{C}$.

\section{Solid state fermentation (SSF) Vs submerged fermentation $(\mathrm{SmF})$}

The comparative study of the SSF and SmF was carried out using the four substrates as the sole carbon source.

\section{Submerged fermentation}

In $\mathrm{SmF}$, the fermentation medium $(\mathrm{g} / \mathrm{L}$ :

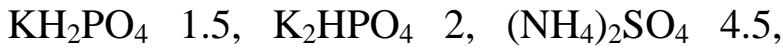
Yeast extract 0.075 , Peptone 0.075 , Tween 80 $0.075, \mathrm{ZnSO}_{4} .7 \mathrm{H}_{2} \mathrm{O} 140 \mathrm{mg}, \mathrm{MnSO}_{4} \cdot \mathrm{H}_{2} \mathrm{O} 160$ $\mathrm{mg}, \mathrm{FeSO}_{4} \cdot 7 \mathrm{H}_{2} \mathrm{O} 500 \mathrm{mg}, \mathrm{COCl}_{2} \cdot 2 \mathrm{H}_{2} \mathrm{O} 200$ $\mathrm{mg}, \mathrm{pH} .7 .0$ ) was used and each of the four substrates were added at $2 \%(\mathrm{w} / \mathrm{v})$ in separate conical flasks, inoculated and incubated at $35^{\circ} \mathrm{C}$ for $120 \mathrm{~h}$ on an orbital shaker. Each sample was then centrifuged at 10,000 rpm and at $4^{\circ} \mathrm{C}$ for $20 \mathrm{~min}$, and the clear supernatant was assayed for xylanase activity.

\section{Solid state fermentation}

The medium for SSF contained $10 \mathrm{~g}$ of each of four substrates and $6 \mathrm{~mL}$ of the mineral salt solution: $\mathrm{g} / \mathrm{L}: \mathrm{KH}_{2} \mathrm{PO}_{4} \quad 1.5, \mathrm{~K}_{2} \mathrm{HPO}_{4} \quad 2$, $\left(\mathrm{NH}_{4}\right)_{2} \mathrm{SO}_{4} 4.5$, Yeast extract 0.075, Peptone 0.075 , Tween $800.075, \mathrm{ZnSO}_{4} .7 \mathrm{H}_{2} \mathrm{O} 140 \mathrm{mg}$, $\mathrm{MnSO}_{4} \cdot \mathrm{H}_{2} \mathrm{O} 160 \mathrm{mg}, \mathrm{FeSO}_{4} .7 \mathrm{H}_{2} \mathrm{O} 500 \mathrm{mg}$, $\mathrm{COCl}_{2} \cdot 2 \mathrm{H}_{2} \mathrm{O} 200 \mathrm{mg}$, Moisture: 6\%, pH:7.0). The media was inoculated and incubated at $35^{\circ} \mathrm{C}$. After 5 days of incubation, the enzyme was extracted from the SSF media according to the method of Alva et al., (2007).

\section{Xylanase assay}

Xylanase activity was determined using beechwood xylan (Sigma, Germany) (Bailey et al., 1992). A $0.2 \mathrm{~mL}$ culture supernatant was added to $1 \mathrm{~mL}$ xylan solution $(1 \% ; \mathrm{pH}$ $7.0 ; 100 \mathrm{mM}$ sodium phosphate buffer) and incubated at $55^{\circ} \mathrm{C}$. After $30 \mathrm{~min}, 3 \mathrm{~mL} \mathrm{3,5-}$ dinitrosalicylic acid reagent was added to stop the reaction, and the amount of reducing sugars released in the reaction was estimated by measuring the absorbance at $540 \mathrm{~nm}$ (Miller, 1959). A control was run concurrently which contained all the reagents but the reaction was terminated prior to the addition of enzyme extract. One unit of xylanase activity was defined as the amount of enzyme catalysing the release of $1 \mu \mathrm{mol}$ of reducing sugar equivalent to xylose per min under the specified assay conditions. All the experiments were carried out independently in triplicate and the results presented are mean of the three values.

\section{Selection of basal medium}

3 different media, A (Techapun et al., 2003), B (M9 medium) (Roy, 2004) and C (Mandels and Sternburg, 1976) were used for comparative studies to find the appropriate basal nutrient medium for the further formulation of the optimal medium.

\section{Optimisation of fermentation conditions}

The optimum conditions for enzyme production were studied such as time course of fermentation (1-5days), initial medium $\mathrm{pH}$ (6.0-9.0), incubation temperature $\left(30-40^{\circ} \mathrm{C}\right.$ with $5^{\circ} \mathrm{C}$ interval), inoculum age $(16 \mathrm{~h}, 20 \mathrm{~h}$ and $24 \mathrm{~h}$ ), agitation speed (50,100and 150 $\mathrm{rpm})$, salinity ( 0 ppt $-20 \mathrm{ppt})$, substrate concentration (0.5-3\%) and various nutritional conditions such as additional carbon sources (xylose, glucose, sucrose, cellulose, xylan, starch and glycerol), surfactants (Tween 60, 
Tween 80) and other additives (olive oil and polyethylene glycol), nitrogen sources (tryptone, beef extract, yeast extract, peptone, albumin, casein, soya bean meal, urea, ammonium chloride, di ammonium phosphate, ammonium sulphate and potassium nitrate)

\section{Statistical analysis}

All experiments were carried out in triplicates, the standard deviation for each experimental result was calculated using Microsoft Excel 2003and statistically evaluated using ANOVA at a significance level of $p<0.05$ by using computer based program SPSS (Version 17.0, Chicago, SPSS Inc.).

Application of crude xylanase in deinking of newspaper

\section{Preparation of paper pulp}

Old newspapers were pulped by soaking wet in hot water for $2 \mathrm{~h}$ and crushed in a domestic mixer with added $0.1 \%$ Tween 80 . The pulp was dried at $50^{\circ} \mathrm{C}$ and stored in sterile container at $4{ }^{\circ} \mathrm{C}$ until further use (Mohandass and Raghukumar, 2005).

\section{Deinking trials using cell-free bacterial culture supernatants}

Streptomyces sp. ER1 was grown in nutrient broth supplemented with Tween 80 and xylan. After 5 days of incubation, the medium was centrifuged and the clear cell-free supernatant was used. The pulp was soaked wet in water for $30 \mathrm{~min}$, prepared at 3-9\% consistency and sterilized by autoclaving. It was then incubated with $50 \mathrm{~mL}$ of the cell-free supernatant for 5 days. The pulp was washed thoroughly with tap water and filtered over a Buchner funnel under suction to obtain in a form of hand sheets. The hand sheets were pressed flat using two stainless steel plates and oven-dried at $50^{\circ} \mathrm{C}$ for 5 days. Newspaper pulp without treatment with actinomycete culture was used as control (Mohandass and Raghukumar, 2005).

\section{Analysis of collected filtrate}

The colour removal from the pulp was analysed with a spectrophotometer from $\lambda 200$ $\mathrm{nm}$ and $\lambda 800 \mathrm{~nm}$. The phenolic and hydrophobic compounds released were measured by measuring the absorbance at $\lambda$ $237 \mathrm{~nm}$ and $\lambda 465 \mathrm{~nm}$, respectively (Patel et al., 1993; Gupta et al., 2000).

\section{Results and Discussion}

\section{Comparison of SmF and SSF}

The results demonstrated that the used isolate, was able to grow and produce xylanase in SmF even more than SSF (Table 1). Further studies on optimisation of culture conditions and media optimisation were carried out in SmF. Currently, $80-90 \%$ of xylanase are produced in submerged culture as the microbial biomass and the substrates are homogeneously distributed in a liquid medium (Hooi Ling, 2014). Most of the studies proved that SSF was a better fermentation technique for xylanase production using agro wastes but the present study reports contrasting results. The decrease in enzymatic activity at $120 \mathrm{~h}$ of incubation under SSF may be due to the sporulation of the isolate (Assamoi et al., 2008). Maybe xylanase produced during the first stage of fermentation are degraded or denaturalised after onset of sporulation during SSF (UmszaGuez et al., 2011).

\section{Selection of substrates for maximum} xylanase production

Among all the four substrates, the maximum xylanase yield was observed for corn cob 
(7394.4 U/mL) followed by sugarcane bagasse $(6965.067 \mathrm{U} / \mathrm{mL})$, water hyacinth $(5984 \mathrm{U} / \mathrm{mL})$ and coconut oil cake (4608.133 $\mathrm{U} / \mathrm{mL}$ ) in submerged fermentation suggesting the application of these agro residues for xylanase production. The eminent xylan content in corn cob (40\%), the maximum among all agricultural waste, makes it a prospective substrate for xylanase production (Boonchuay et al., 2016). There are many previous reports on the superiority of corn cob as a substrate for xylanase production (Gupta and Kar, 2009; Shanab et al., 2010). Apart from agricultural byproducts, the novel substrate considered in this study is a pest plant- water hyacinth (Perez et al., 2013; Nagar et al., 2010). Its high reproduction rate causes abundant problems like eutrophication, obstruction of rivers, hampers fishing and endangers the existing flora and fauna by preventing the penetration of sunlight. The use of water hyacinth as a suitable substrate is being carefully considered as they do not compete for land, have a insignificant cost and grow rapidly. Sufficient study has not been conducted on water hyacinth, in spite of its higher carbohydrate content (Nagar et al., 2010).

\section{Effect of different media:}

Highest xylanase activity was found in the production medium Medium A for both substrates coconut oilcake and water hyacinth while the Medium B (M9 medium) was found optimum for corn cob and sugarcane bagasse (Table 2). The presence of yeast extract and peptone in production medium A might have positively affected the xylanase production using coconut oil cake and water hyacinth. Additionally, the release of ammonium ion from peptone also stimulated the growth of microorganism, thus producing higher xylanase activity (Sanghi et al., 2009). Thus, the optimum medium formulation with essential growth-limiting nutrients is significant to optimise and increase the xylanase productivity. Lower xylanase activity observed from medium $\mathrm{C}$ was most likely owing to the different composition of the medium that was less favourable by Streptomyces sp.ER1. ANOVA indicated that the enzyme activity is significant $(\mathrm{p} \leq 0.05)$.

\section{Effect of incubation period for xylanase production}

The production of xylanase from Streptomyces sp. ER1 in different time periods (24 to $120 \mathrm{~h}$ ) exhibited that highest xylanase production was found at $72 \mathrm{~h}$ of fermentation and has given the activity of $4608.14 \mathrm{U} / \mathrm{mL}(\mathrm{P}<0.01)$ with coconut oil cake; $7491.87 \mathrm{U} / \mathrm{mL}(\mathrm{P}<0.01)$ with corn cob; $6965.07 \mathrm{U} / \mathrm{mL} \quad(\mathrm{P}<0.01)$ with sugarcane bagasse and $5930 \mathrm{U} / \mathrm{mL}(\mathrm{P}>0.05)$ with water hyacinth. Similar results were reported by Gupta and Kar (2009) and Ahmad et al., (2012). After $72 \mathrm{~h}$ of incubation, the xylanase activities decreased which might be due to both reduction of the nutrients and by the proteolytic enzyme present in the culture medium (Figure 1a). Shorter fermentation time $(72 \mathrm{~h})$ is favourable for greater costeffective industrial xylanase production.

\section{Effect of inoculum age}

The production of xylanase from different inoculum age of Streptomyces sp. ER1 (16, 20 and $24 \mathrm{~h}$ ) revealed that maximum xylanase activity was yielded with $5 \%(\mathrm{v} / \mathrm{v})$ of 20 -hour inoculum from sugarcane bagasse (7438 $\mathrm{U} / \mathrm{mL}) \quad(\mathrm{P}<0.01)$, water hyacinth $(5948.2$ $\mathrm{U} / \mathrm{mL})(\mathrm{P}<0.01)$, corn cob $(7535.2 \mathrm{U} / \mathrm{mL})$ $(\mathrm{P}<0.01)$ and coconut oil cake $(5333.334$ $\mathrm{U} / \mathrm{mL})(\mathrm{P}<0.01)$. Inoculum of age above $20 \mathrm{~h}$ did not support enhanced levels of xylanase production (Figure 1b). However, less xylanase production with $16 \mathrm{~h}$ old inoculum, might be because Streptomyces sp, ER1 might not have entered into log phase of growth. 
The inoculum age of Streptomyces sp. is important as it might have caused in the transfer of high quantities of spores if transferred during the stationary phase or death phase and in the long lag phase of the fermentation profile.

\section{Effect of salinity}

The effect of salinity on xylanase production was studied by preparing the respective production media with different salinity ranging from $0 \mathrm{ppt}$ to $20 \mathrm{ppt}$. The study shows that 20 ppt salinity was optimum for maximum xylanase production from sugarcane bagasse $(7631.6 \mathrm{U} / \mathrm{mL})(\mathrm{P}<0.05)$, water hyacinth $(5971.667 \mathrm{U} / \mathrm{mL})(\mathrm{P}>0.05)$, corn cob $(7652.133 \mathrm{U} / \mathrm{mL}) \quad(\mathrm{P}<0.05)$ and coconut oil cake $(5600.54 \mathrm{U} / \mathrm{mL}) \quad(\mathrm{P}<0.05)$ (Figure 1c). It exhibits the halophilic nature of Streptomyces sp. ER1.

\section{Effect of initial pH}

The initial $\mathrm{pH}$ of the medium is critical for growth and enzyme production as the metabolic activities of microorganisms are very susceptible to $\mathrm{pH}$ change (Rekha et al., 2012). Streptomyces sp. ER1 showed maximum production in a neutral $\mathrm{pH}$ of 7.0 and the production decreased with increase in $\mathrm{pH}$ (Figure 1d) with coconut oil cake $(\mathrm{P}<0.01)$, corn cob $(\mathrm{P}<0.01)$ and sugarcane bagasse $(\mathrm{P}<0.01)$ as substrates. However, $\mathrm{pH}$ 8 was found optimum for xylanase production with water hyacinth $(\mathrm{P}>0.05)$ as the substrate. Similar results were observed by Ahmed et al., (2012) and Rahmani et al., (2014). All the substrates exhibited good activity from $\mathrm{pH} 6.0$ to 9.0 indicating the alkalophilic nature of the xylanase produced and thus could be applied in detergent and textile industries. The inconsistency in optimum $\mathrm{pH}$ in different media is dependent on the nature of the substrate and that the enzyme might interact with other media or extract components (Santos et al., 2013).

\section{Effect of incubation temperature}

The strain ER1 showed maximum production at $40^{\circ} \mathrm{C} \quad(\mathrm{P}<0.01)$ and the production decreased with increase in temperature (Figure 1e) with coconut oil cake and sugarcane bagasse as substrates. However, $35^{\circ} \mathrm{C} \quad(\mathrm{P}<0.01)$ was found optimum for xylanase production with water hyacinth and corn cob as substrates. Similar results were observed in previous studies (Sivaramakrishnan et al., 2009; Knob et al., 2014). Streptomyces sp. ER1, could be qualified as thermotolerant, owing to its inclination towards higher temperature for xylanase production. Thus it might have great role in industrial applications (Immanuel et al., 2006).

\section{Effect of agitation}

Enzyme production by Streptomyces sp. ER1 with the selected substrates was studied for growth under agitation (50,100 and $150 \mathrm{rpm})$. In our study, $50 \mathrm{rpm}(\mathrm{P}<0.05)$ was found optimum for xylanase production using coconut oil cake $(6620.8 \mathrm{U} / \mathrm{mL})$ and sugarcane bagasse $(7964.54 \mathrm{U} / \mathrm{mL})$ as substrates while $100 \mathrm{rpm} \quad(\mathrm{P}<0.05)$ was optimum for corn cob $(7875 \mathrm{U} / \mathrm{mL})$ and water hyacinth $(6124.47 \mathrm{U} / \mathrm{mL})$ as substrates (Figure 1f). As agitation speed increased; the higher shear force might have caused lower xylanase production. Similar results were observed by Hooi Ling (2014) and Nasr et al., (2013).

\section{Effect of substrate concentration}

With increasing concentrations of substrates, a substantial increase in enzyme production was recorded (Figure 1g). 2\% of coconut oil cake, $2.5 \%$ of corn cob and water hyacinth; and 3\% sugarcane bagasse were found to be optimum for maximum xylanase production $(\mathrm{P}<0.01)$. Similar results were observed by 
Bhosale et al., (2011) and Sepahy et al., (2011).

\section{Effect of nitrogen sources}

Different nitrogen sources were studied for their effect on xylanase production by Streptomyces sp. ER1. The results are depicted in Figures $1 \mathrm{~h}$ and 1i. Among all the organic nitrogen sources tested, peptone, soya bean meal, albumin and urea were found to be the best inducer for xylanase production from coconut oil cake, Corn cob, sugarcane bagasse and water hyacinth respectively and drastically increased xylanase activity $(\mathrm{P}<0.01)$. Among the inorganic sources, ammonium chloride produced a maximum xylanase activity from coconut oil cake and corn cob and drastically increased xylanase activity $(\mathrm{P}<0.05)$; ammonium sulphate for sugarcane bagasse and potassium nitrate for water hyacinth were found to be optimum for xylanase production and significantly increased xylanase activity $(\mathrm{P}<0.01)$. Peptone releases $\mathrm{NH}^{+4}$ ions, which stimulates growth and enzyme yield due to its protease inhibiting nature at low concentration (Bajaj and Abbas, 2011). Soybean meal does not cause catabolite repression and contains approximate all kinds of amino acids (ElGendy and El-Bondkly, 2014), thus being readily absorbed by Streptomyces sp. ER1 mycelium.

\section{Effect of different surfactants}

Detergent effects on xylanase production by Streptomyces sp. strain ER1 varied with the selected agro waste (Figure 1j). Tween-60, polyethylene glycol and olive oil increased xylanase production in corn cob; coconut oil cake and water hyacinth; and sugarcane bagasse respectively and significantly increased xylanase production $(\mathrm{P}<0.01)$. Similar observations were made by El-Gendy and El-Bondkly (2014).

Table.1 Effect of different substrates on xylanase Production under SmF and SSF

\begin{tabular}{|c|c|c|}
\hline Substrate & \multicolumn{1}{|l}{$\begin{array}{l}\text { SmF }(U / m L) \\
\text { Xylanase activity }\end{array}$} & $\begin{array}{c}\text { S SSF }(U / g) \\
\text { Xyanase activity }\end{array}$ \\
\hline Coconut oil cake & $4608.13 \pm 139.47$ & $3069.33 \pm 100.1$ \\
\hline Water hyacinth & $5984 \pm 149.84$ & $1001.79 \pm 11.89$ \\
\hline Sugarcane baggase & $6965.067 \pm 170.1$ & $1421.33 \pm 14.2$ \\
\hline Corn cob & $7394.4 \pm 173.9$ & $479.33 \pm 5.0$ \\
\hline
\end{tabular}

Table.2 Xylanase production in different production media with different substrates

\begin{tabular}{|l|l|l|}
\hline Production medium & Substrate & Enzyme activity (U/mL) \\
\hline A & Coconut oil cake & $4608.13 \pm 139.47$ \\
& Corn cob & $5255.73 \pm 149.84$ \\
& Sugarcane baggase & $1628.67 \pm 170.1$ \\
& Water hyacinth & $5138.67 \pm 173.9$ \\
\hline B (M9 medium) & Coconut oil cake & $301.86 \pm 3.0$ \\
& Corn cob & $7491.87 \pm 174.9$ \\
& Sugarcane bagasse & $6997.1 \pm 179.9$ \\
& Water hyacinth & $2226.67 \pm 121.8$ \\
\hline C & Coconut oil cake & $3861.47 \pm 138.1$ \\
& Corn cob & $4805.33 \pm 138.3$ \\
& Sugarcane bagasse & $6289.33 \pm 172.9$ \\
& Water hyacinth & $3413.33 \pm 134.3$ \\
\hline
\end{tabular}


Figure.1a Effect of incubation period for xylanase production using selected substrates

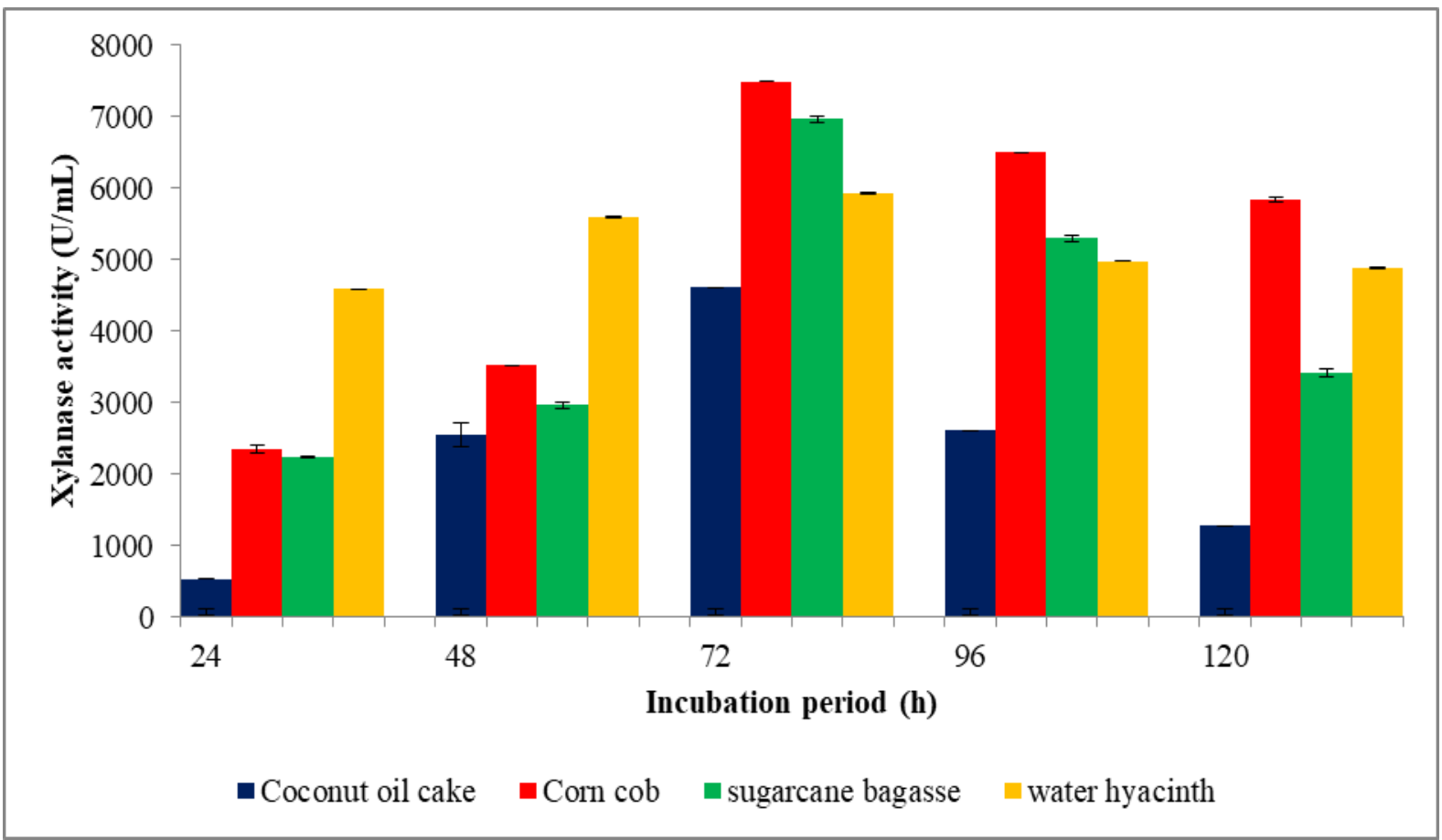

Figure.1b Effect of inoculums age (h) for xylanase production using selected substrates

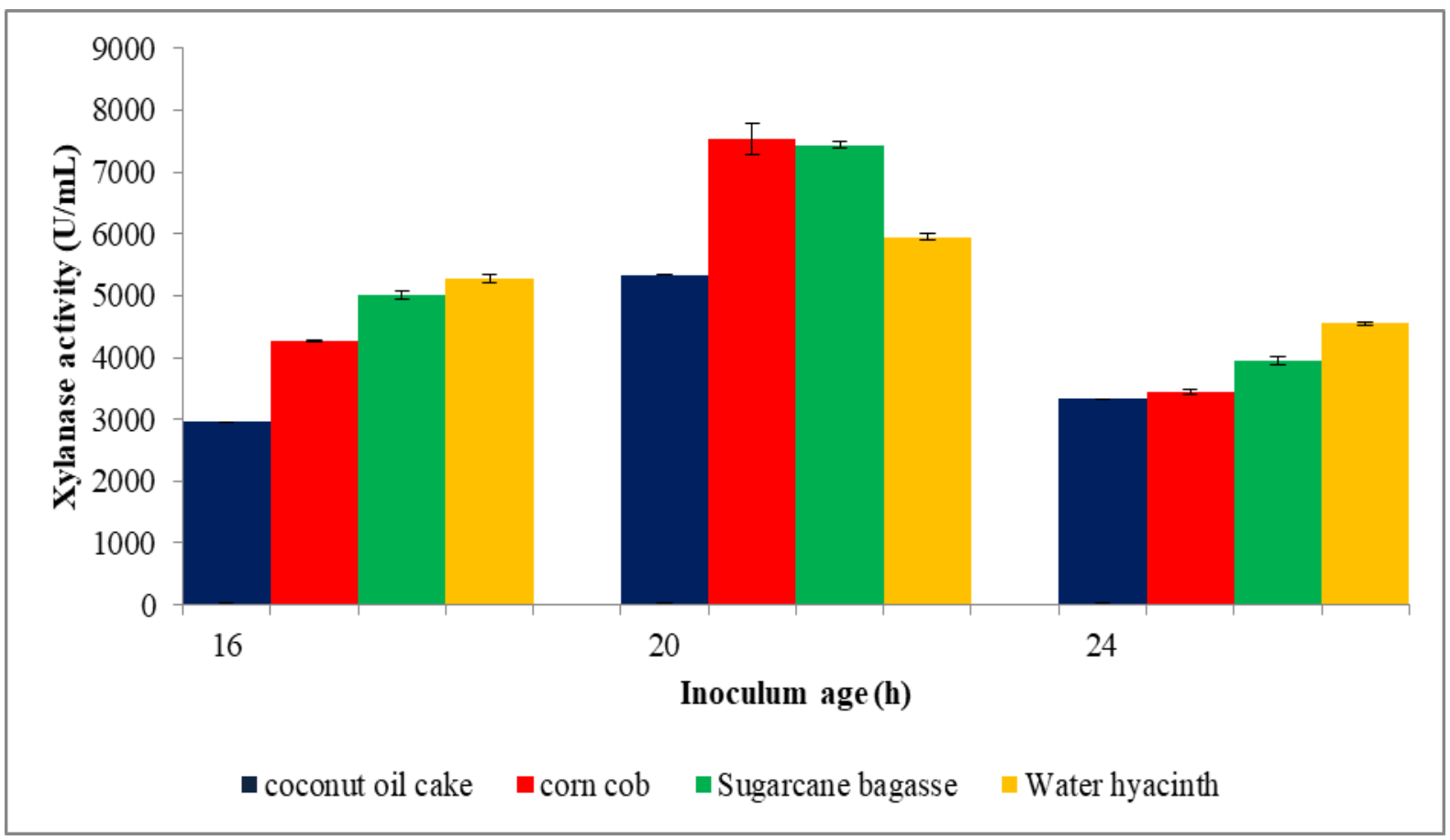


Figure.1c Effect of salinity (ppt) for xylanase production using selected substrates

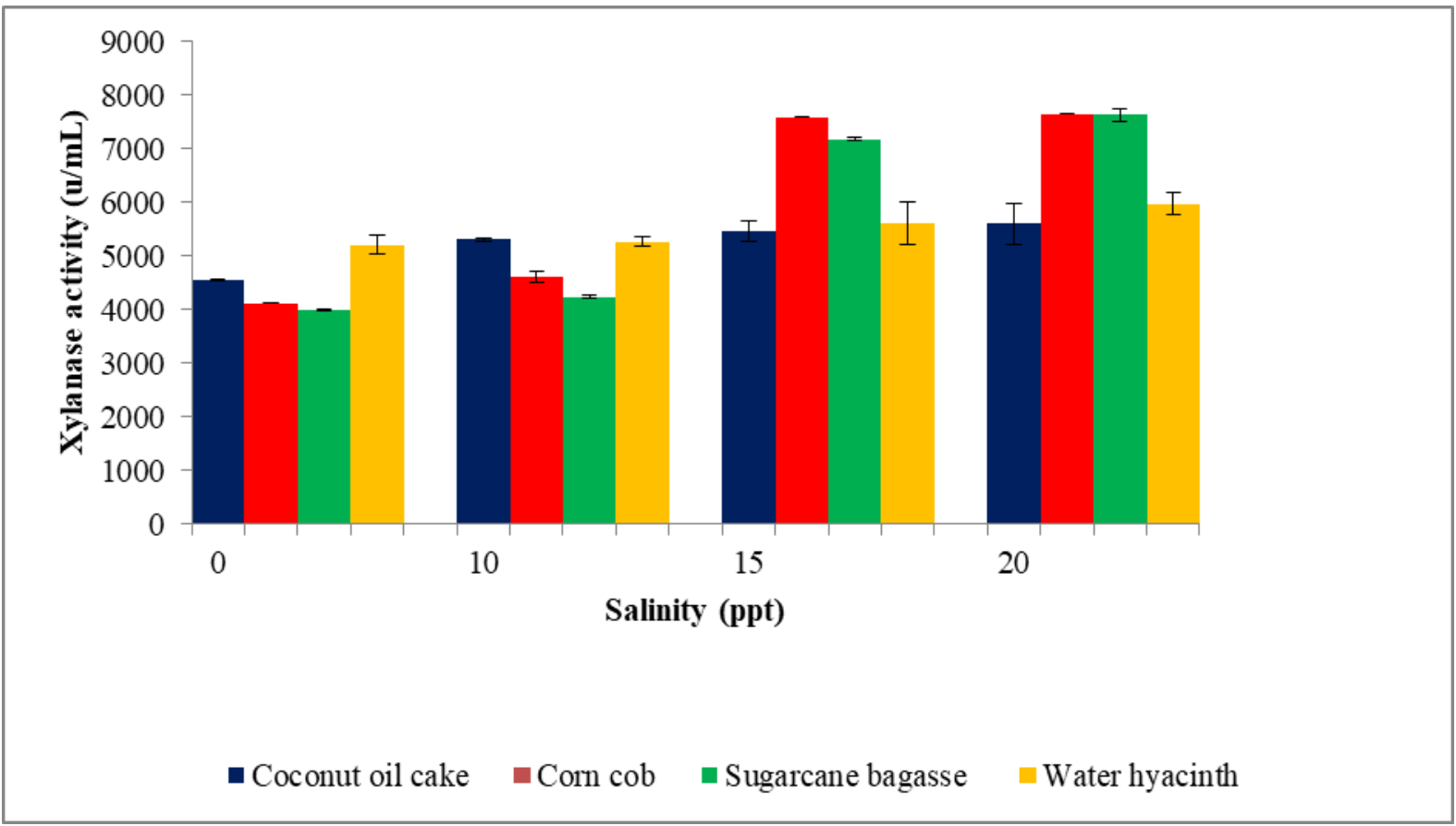

Figure.1d Effect of $\mathrm{pH}$ on xylanase production using selected substrates

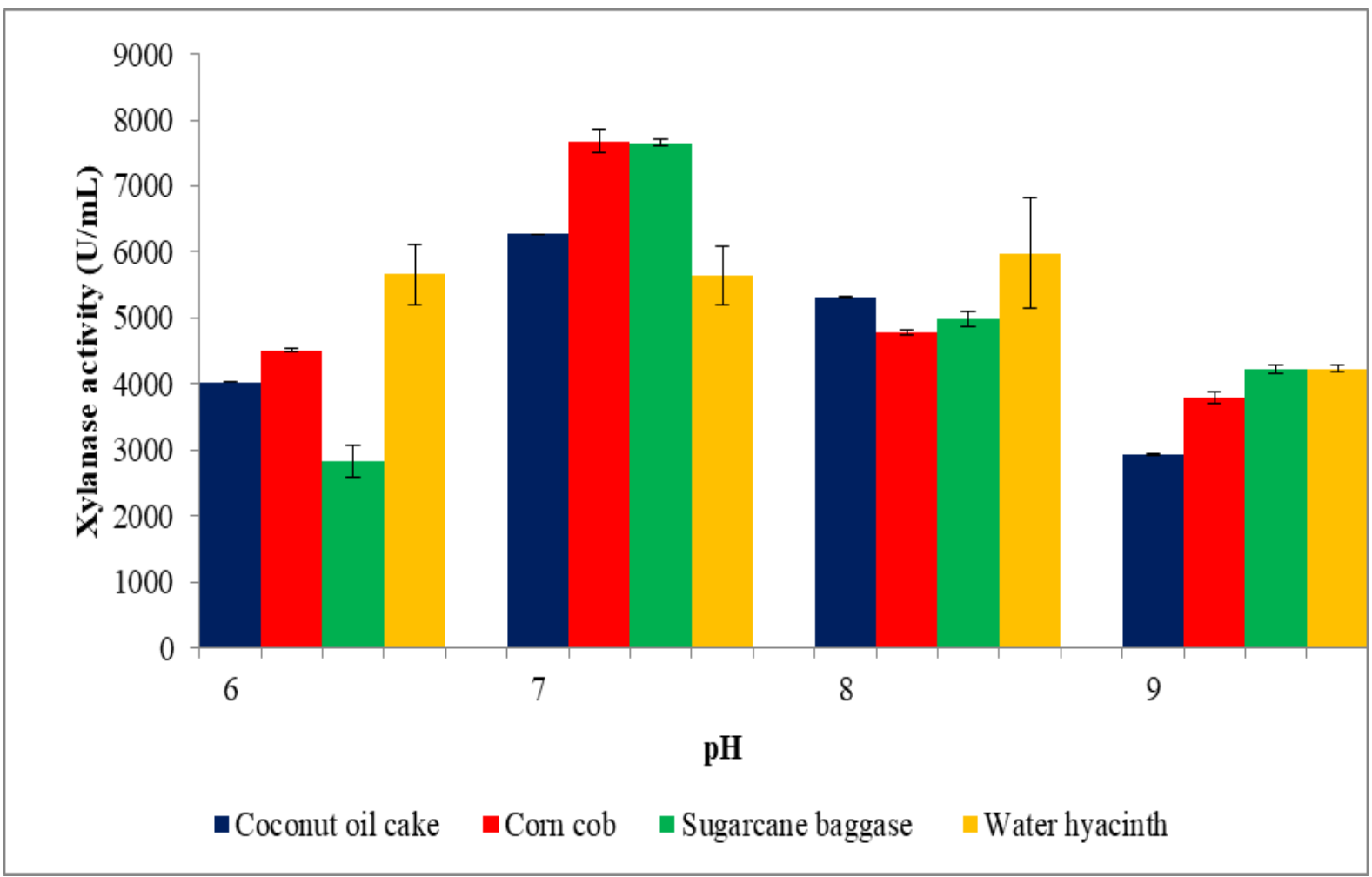


Figure.1e Effect of incubation temperature on xylanase production using selected substrates

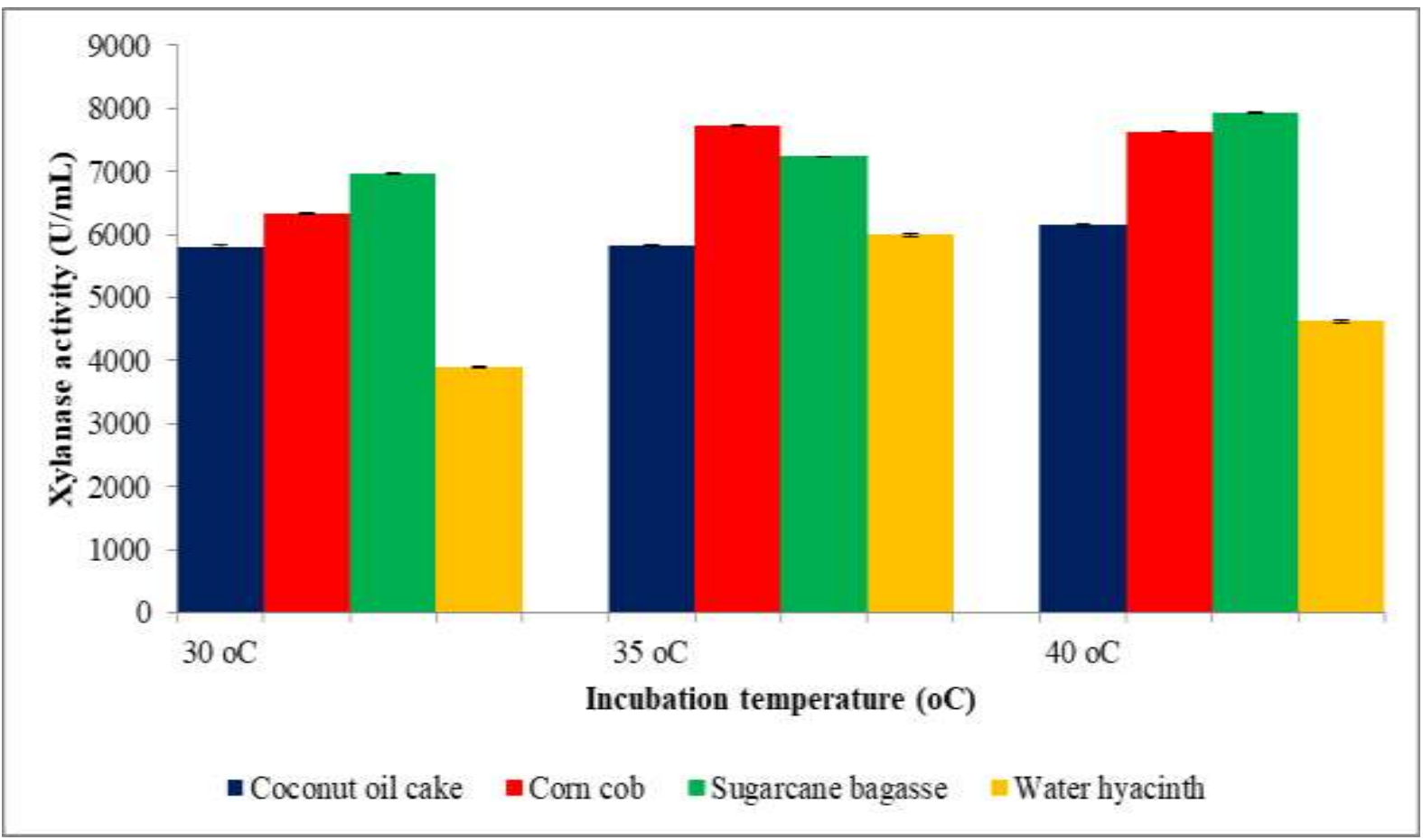

Figure.1f Effect of agitation speed (rpm) for xylanase production using selected substrates

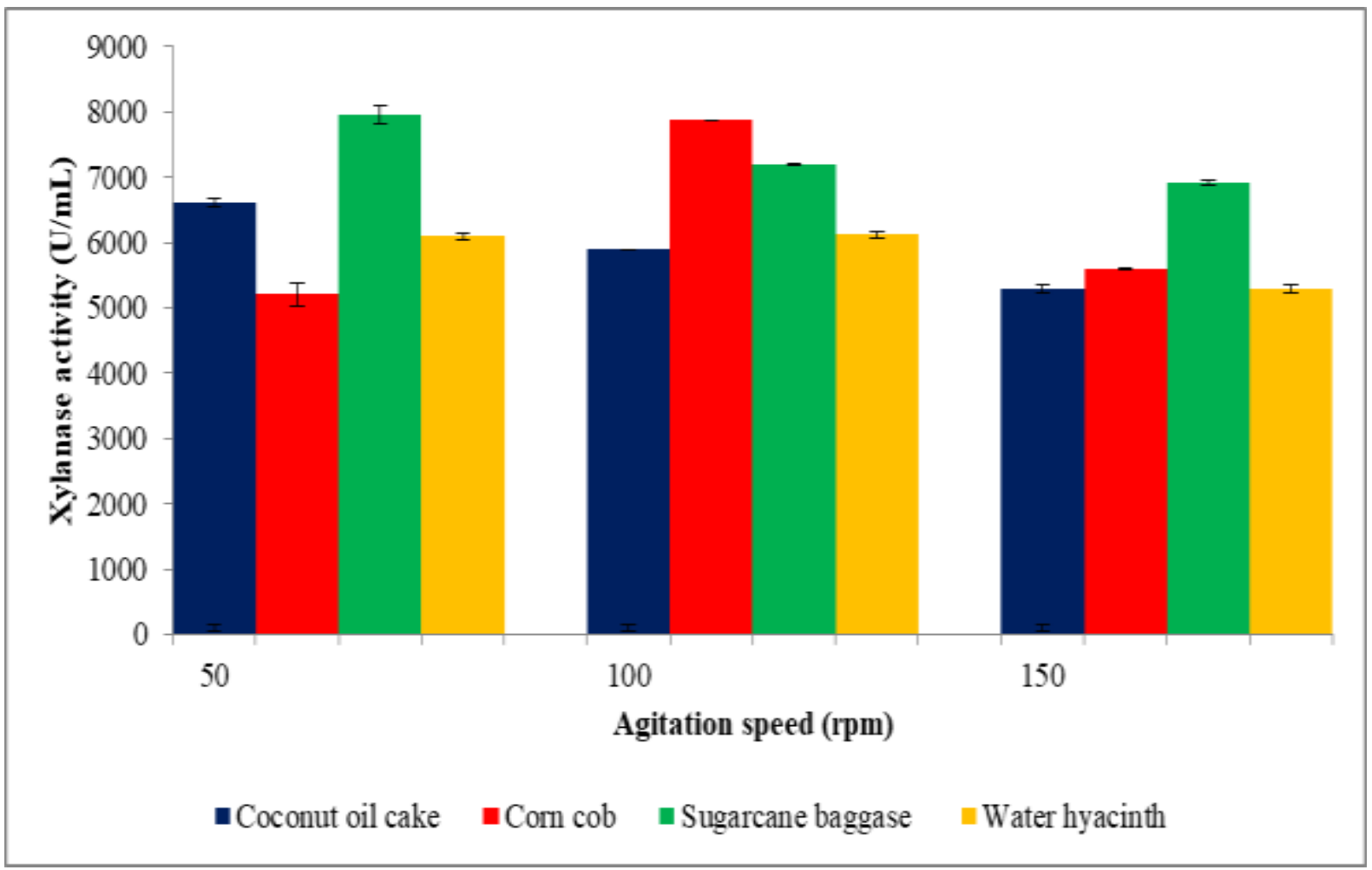


Figure.1g Effect of substrate concentration (\%) on xylanase production using selected substrates

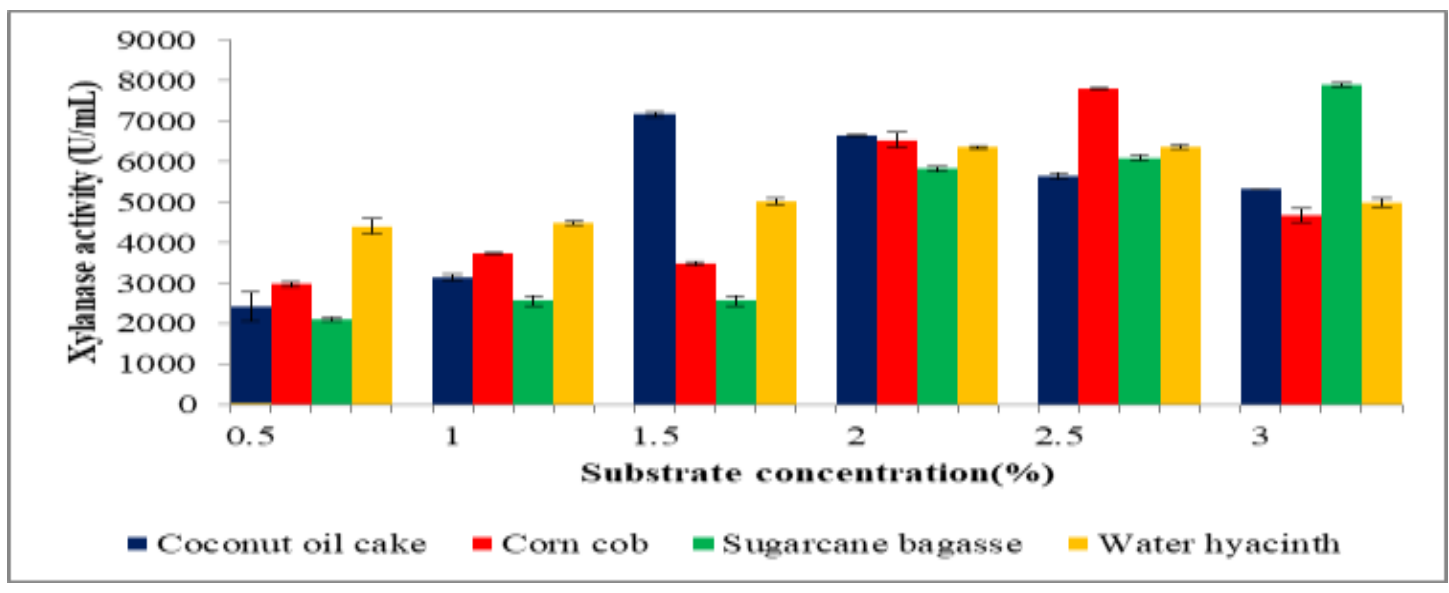

Figure.1h Effect of inorganic nitrogen sources on xylanase production using selected substrates

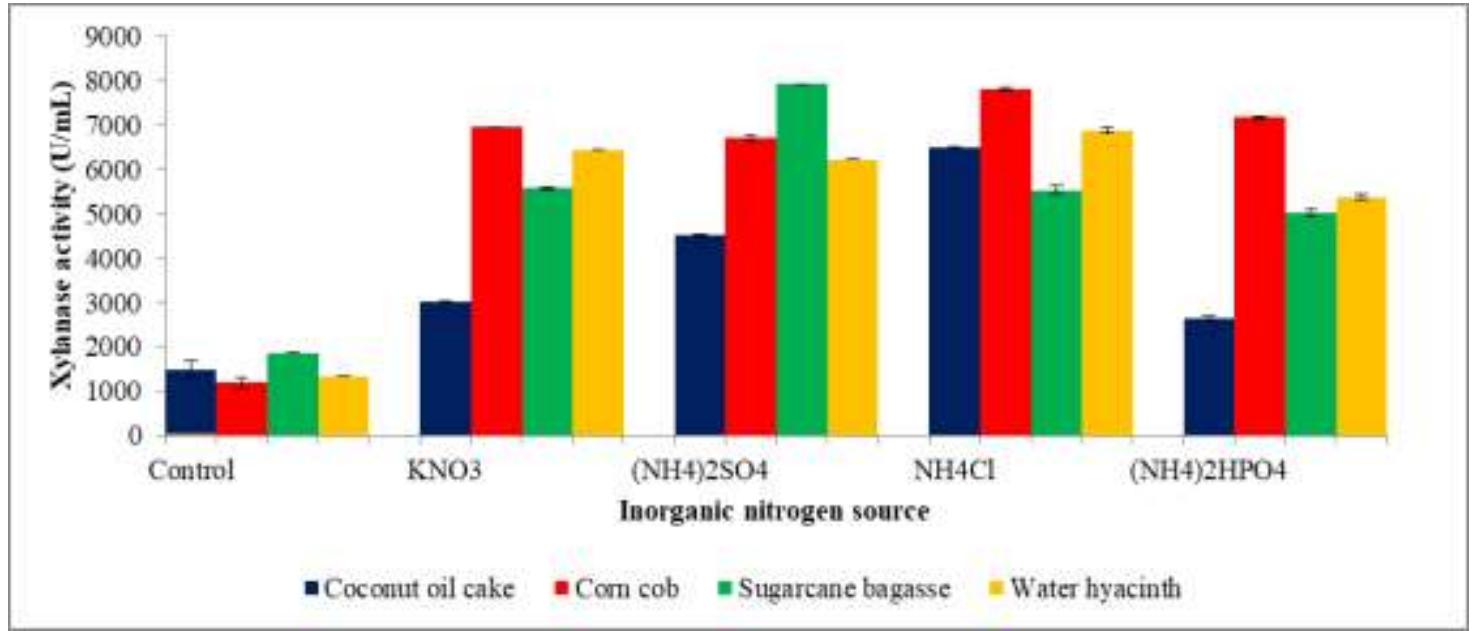

Figure.1i Effect of organic nitrogen sources on xylanase production using selected substrates

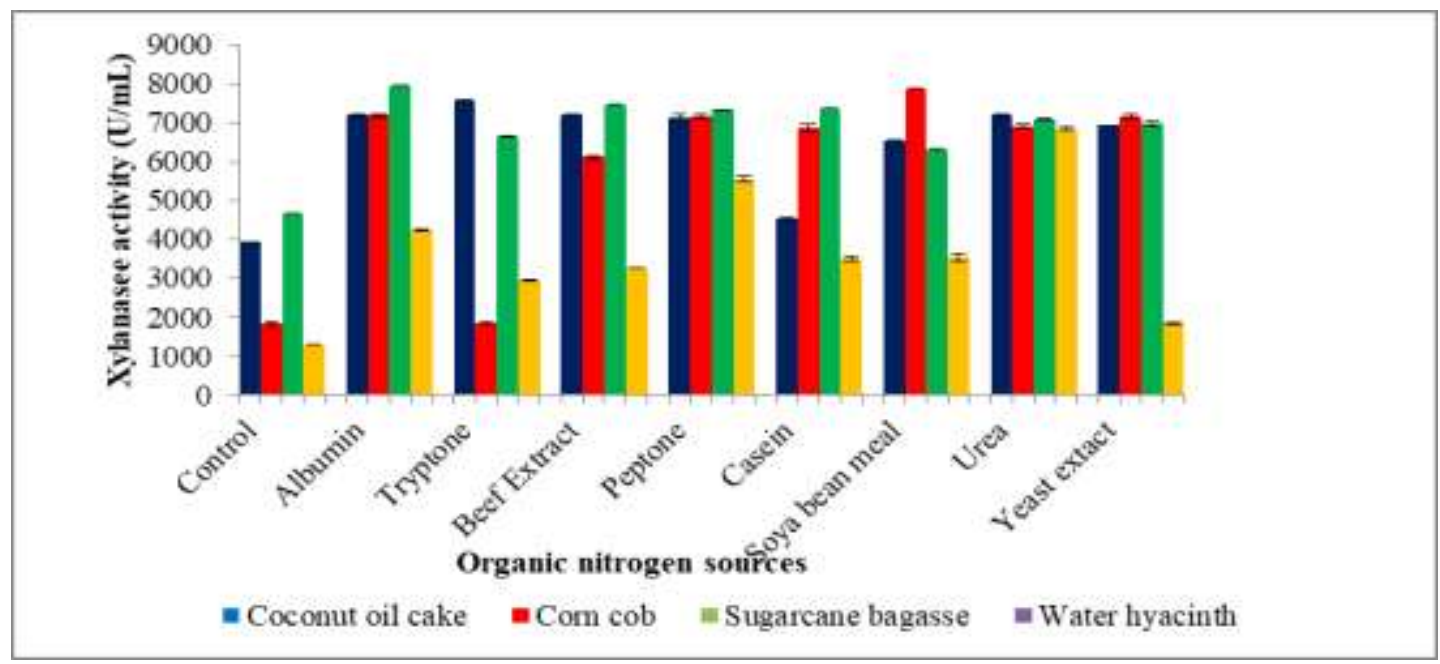


Figure.1j Effect of surfactants on xylanase production using selected substrates

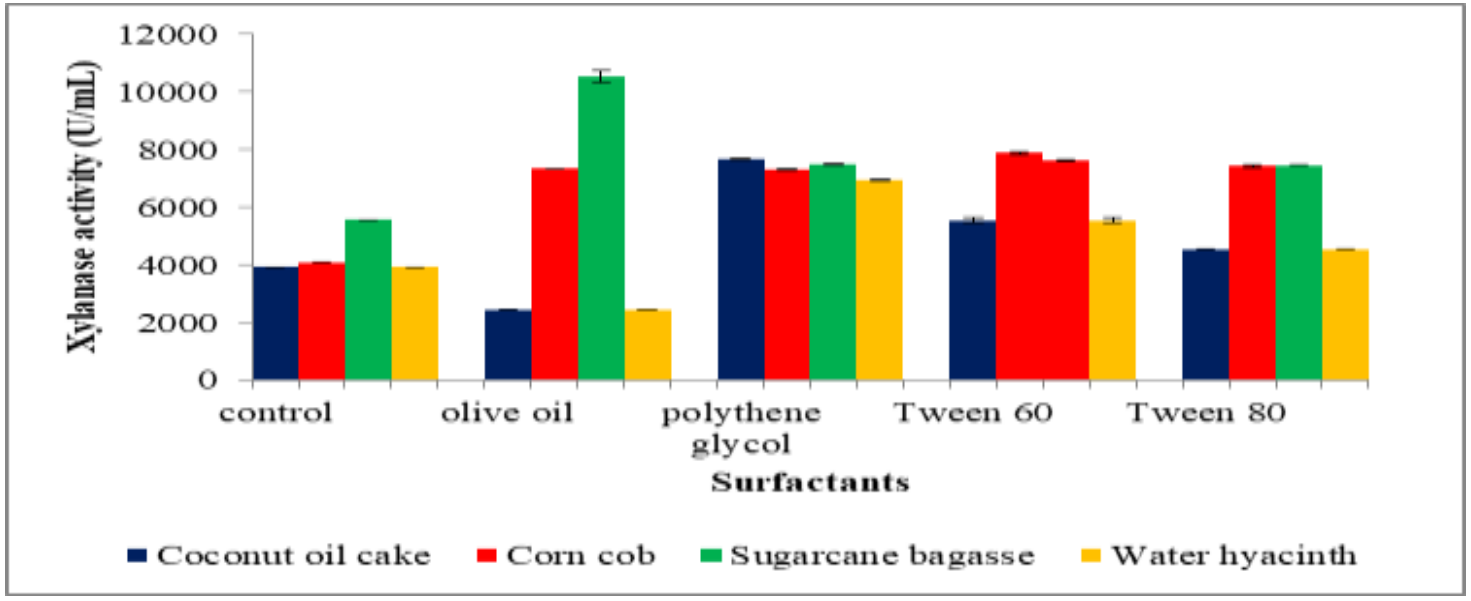

Fig.2 Manually pressed pulp before and after treatment with xylanase

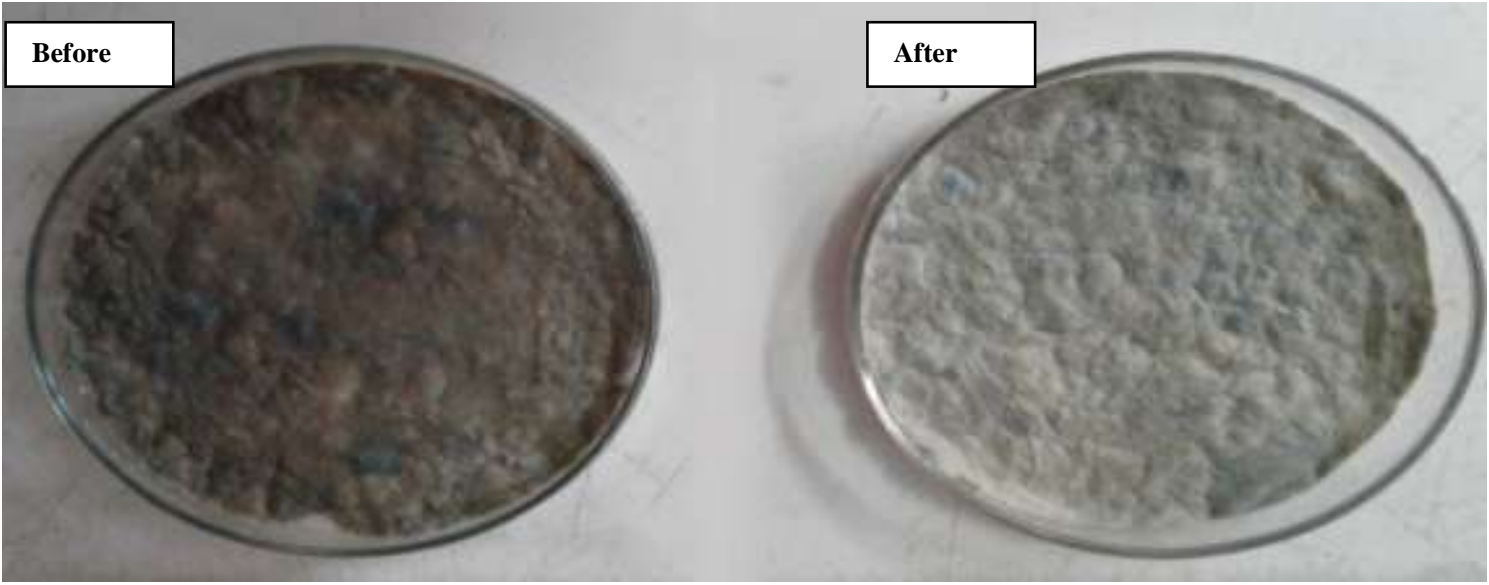

Fig.3 Analysis of phenolic compounds and hydrophobic compounds in effluents released from the paper pulp before and after the enzyme treatment

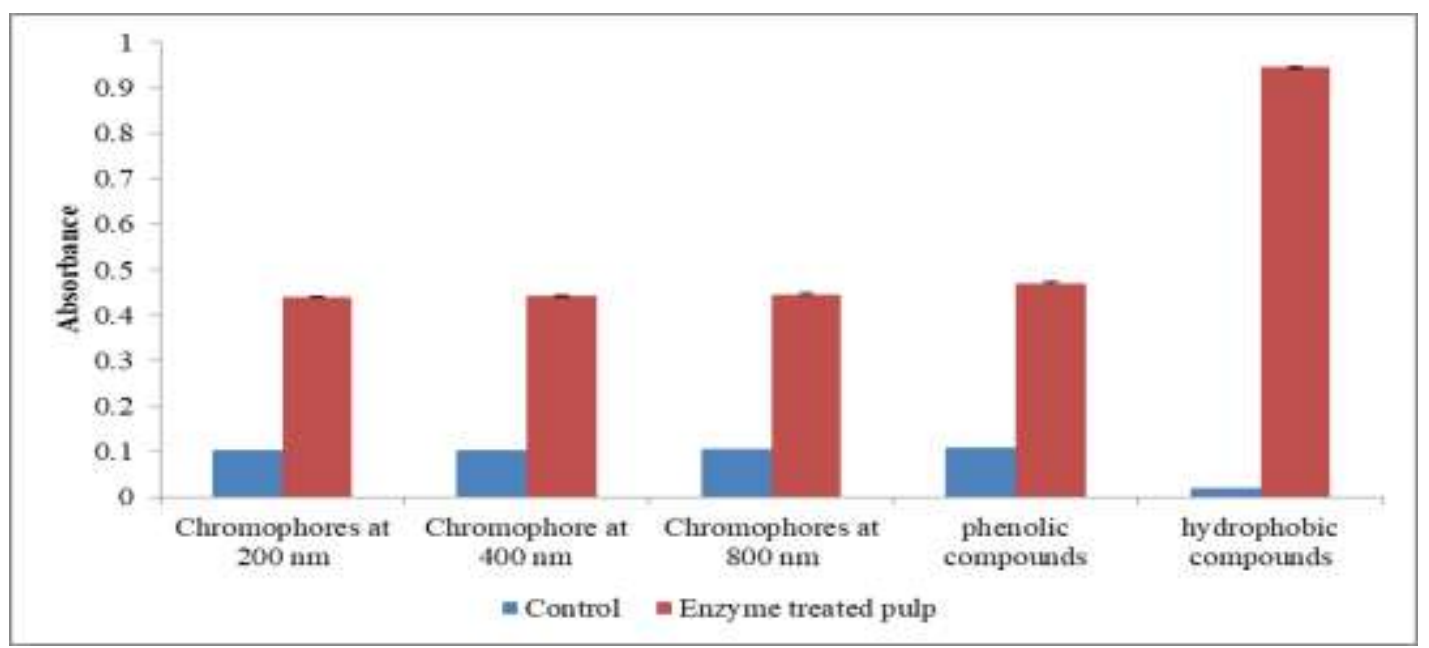


Stimulatory effect of Tween 60 and olive oil on xylanase production could be due to the effect on cell membrane permeability or by disrupting nonspecific binding of enzymes to substrates. These actions exerts a positive effect on desorption and recycling of xylanase.

Analysis of phenolic compounds and hydrophobic compounds in effluent released before and after xylanase treatment

The results of the current study clearly indicated that the cell-free culture supernatants of Streptomyces sp. strain ER1 showed tremendous potential for biological deinking. Treatment with cell-free culture supernatant containing xylanase activity caused several folds of increase in brightness (Figure 2). This might have caused either by decolourization alone or both decolourization and dislodging of ink particles from pulp fibre. On comparing the absorbance of effluents ( $\lambda 200$ to $800 \mathrm{~nm}$ ), it was found that xylanase treated pulp effluent showed high absorbance whereas that of control were colourless (Figure 3). Highly purified or concentrated enzymes are being used for deinking purpose (Marques et al., 2003) but, in the current study, the crude culture supernatant alone could bring about deinking of newspaper.

In summary, Streptomyces sp. ER1 was identified to be potential xylanase producer but need further studies as xylanase production from Streptomyces sp. of Cochin estuary is not well documented. The xylanase enzyme was successfully produced from all agro-industrial wastes tested and sugarcane bagasse was found to be best suited for xylanase production after optimisation. The ability of Streptomyces sp. ER1 to produce xylanase on several substrates made it possible to use suitable substrate according to the seasons, cost effectively and the optimization study in the present work may assist this purpose. The study proves that optimal conditions for xylanase production varied with the substrates and thus it is critical to maintain optimal conditions for maximum enzyme production with each substrate. The crude xylanase produced by the stain ER1 could successfully decolourise the old newspaper samples. Hence, Streptomyces sp. strain ER1 can be considered as a promising agent for xylanase production using agricultural wastes which help in converting waste materials in to commercially important valuable products and also its application in deinking used paper.

\section{Conflict of interest statement}

We declare that we have no conflict of interest.

\section{Acknowledgements}

The authors are grateful to UGC-BSR, India for funding this research. We also thank Department of Marine Biology, Microbiology and Biochemistry and National Centre of Aquatic Animal and Health, CUSAT, Kerala, for providing facilities.

\section{References}

Ahmed, Z., Butt, M. S., Anjum, M. F., et al., 2012. Effect of corn cobs concentration on xylanase biosynthesis by Aspergillus niger. Afr. J. Biotechnol. 11(7), 1674-1682.

Ali, S., Sayed, A., Sarker R.T., Alam, R. 1991. Factors affecting Cellulase Production by Aspergillus terreus. World. J. Microbiol. Biotechnol. 7, 62-66.

Alva, S., Anupama, J., Salva, J., Chiu, Y. Y., Vyashali, P., Shruti, M., Yogeetha, B. S., Bhavya, D., Purvi, J., Ruchi, K., 
Kumudini, B.S. and Varalakshmi, K. N. 2007. Production and characterization of fungal amylase enzyme isolated from Aspergillus sp. JGI 12 in solid state culture. Afr. J. Biotechnol., 6, 576-581.

Assamoi, A., Destain, J., Delvigne, F., Lognay, G. and Thonart, P. 2008. Solid-state fermentation of xylanase from Penicillium canescens $10-10 \mathrm{c}$ in a multi-layer-packed bed reactor, Appl. Biochem. Biotechnol. 145, 8798.

Bailey, M.J., Biely, P. and Poutanen, K. 1992. Laboratory testing of method for assay of xylanase activity. J. Biotechnol. 23, 257-270.

Bajaj, B. K. and Abbass, M. 2011. Studies on an alkali-thermostablexylanase from Aspergillus fumigatus MA28. 3 Biotech. 1, 161-171.

Barrios- Gonzalez, J., Gonzalez, H. and Mejia, A. 1993. Effect of particle size, packing density and density and agitation on penicillin production in solid state fermentation. Biotechnol. Adv.11, 539-547.

Bhosale, H. J., Sukalkar, S. R., Uzma, S. Z. and Kadam T. A. 2011. Production of xylanase by Streptomyces rameus grown on agricultural wastes. Biotechnol. Bioinform. Bioengin. $1(4), 505-512$.

Boonchuay, P., Takenaka, S., Kuntiya, A. et al., 2016. Purification, characterization, and molecular cloning of the xylanase from Streptomyces thermovulgaris TISTR1948 and its application to xylooligosaccharide production. J. Mol. Catal. B: Enzy. 129, 61-68.

El-Gendy, M.M.A. and El-Bondkly, A.M.A. 2014. Optimization of Solid State Fermentation and Leaching Process Parameters for Improvement Xylanase Production by Endophytic
Streptomyces sp. ESRAA-301097. J. Microbiol. Biochem. Technol. 6, 154166. DOI: $10.4172 / 1948-$ 5948.1000137.

Gulve, R. M. and Deshmukh, A. M. 2011. Enzymatic activity of actinomycetes isolated from marine sediments. Recent Research in Science and Technology. 3(5), 80-83.

Gupta, S., Bhushan, B. and Hoondal, G. S. 2000. Isolation, purification and characterization of xylanase from Staphylococcus sp SG-13 and its application in biobleaching of kraft pulp. J. Appl. Microbiol. 88, 325-334.

Gupta,U., and Kar, R. 2009. Xylanase production by a thermo-tolerant Bacillus species under solid-state and submerged Fermentation. Braz. Arch. Biol. Technol. 52, 1363-1371.

Ho, H.L. and Lau, L.Y. 2014. Bioprocessing of Agricultural Wastes as Optimised Carbon Source and Optimisation of Growth Conditions for Xylanase Production by Aspergillus brasiliensis in Agitated Solid State Fermentation (Ssf). J. Biodiv. Bioprocess. Dev. 1, 125. DOI:10.4172/23760214.1000125 .

Hooi Ling. 2014. Effects of Medium Formulation and Culture Conditions on Microbial Xylanase Production Using Agricultural Extracts in Submerged Fermentation $(\mathrm{SmF})$ and Solid State Fermentation (SsF): A Review. J. Biodiv. Bioprocess. Dev. 1: 130.

Immanuel, G., Dhanusha, R., Prema, P. and Palavesam, A. 2006. Effect of different growth parameters on endoglucanase enzyme activity by bacteria isolated from coir retting effluents of estuarine environment. Int. J. Environ. Sc. Technol. 3, 25-34.

Knob, A., Fortkamp, P., Prolo, T., Izidoro, S. C. and Almeida, J. M. 2014. Agro 
residues as alternative for xylanase production by filamentous fungi. BioRes. 9(3), 5738-5773.

Lam, K.S. 2006. Discovery of novel metabolites from marine actinomycetes. Curr. Opin. Microbiol. 9 (3), 245-251.

Mandels, M. and Sternburg, D. 1976. Recent advances in cellular technology. J. Ferment. Technol. 54, 267-286.

Marques, S., Pala, H., Alves, L., et al., 2003. Characterization and application of glycanases secreted by Aspergillus terreus CCMI 498 and Trichoderma viride CCMI 84 for enzymatic deinking of mixed office wastepaper. J. Biotechnol. 100, 209-219.

Miller, G.L. 1959. Use of dinitrosalicylic acid reagent for determination of reducing sugar. Anal. Chem. 31, 426-428.

Mohandass, C. and Raghukumar, C. 2005. Biological deinking of inkjet-printed paper using Vibrio alginolyticus and its enzymes. J. Ind. Microbiol. Biotechnol. 32, 424.

Nagar, S., Gupta, V. K., Kumar, D., Kumar, L. and Kuhad, R. C. 2010. Production and optimization of cellulase-free, alkali-stable xylanase by Bacillus pumilus SV- $85 \mathrm{~S}$ in submerged fermentation. J. Ind. Microbiol. Biotechnol. 37, 71-83.

Nasr, S., Soudi, M. R., Hatef Salmanian, A. and Ghadam, P. 2013. Partial Optimization of Endo-1, 4-BXylanase Production by Aureobasidium pullulans Using AgroIndustrial Residues. Iran. J. Bas. Med. Sc. 16(12), 1245-1253.

Patel, A. N., Grabski, A. C. and Jeffries, T. W. 1993. Chromophore release from kraft pulp by purified Streptomyces roseiscleroticus xylanase. App. Microbiol. Biotechnol. 39, 405-412.

Pérez, F. H., Rutiaga-Quiñones, J., AguilarGonzález, C., et al., 2013.
Evaluation of Eichhornia crassipes an Alternative Raw Material for Reducing Sugars Production. BioRes. 8(4), 5340-5348.

Rahmani, N., Robbani, J. U. N., Suparto, H.I. and Yopi, Y. 2014. Optimisation of production xylanase from marine bacterium Bacillus safensis P20 on sugarcane bagasse by submerged fermentation. Int. J. Engin. Sc. 4(6), 31-34.

Rekha, K.S.S., Chandana Lakshmi, M.V.V., Sri Devi, V. and Siddartha Kumar, M. 2012. Production and optimization of lipase from Candida rugosa using groundnut oil cake under solid state fermentation. Int. J. Res. in Engin. Technol. 1 (4), 571-577.

Rosmine, E. and Saramma, A.V. 2016. Isolation of actinomycetes from mangrove and estuarine sediments of Cochin and screening for antimicrobial activity. J. Coast. Life Med. 4(3), 207-210.

Roy, N. 2004. Characterization and identification of xylanase producing bacterial strains isolated from soil and water. Pakistan J. Biol. Sc. 7, 711-716.

Sambrook, J., Fritsch, E. F. and Maniatis, T. 1989. Molecular Cloning. A Laboratory Manual, 2nd edn. Cold Spring Harbor, NY: Cold Spring Harbor Laboratory.

Sanghi, A., Garg, N., Kuhar, N., Kuhad, R. C. and Gupta, V. K. 2009. Enhanced production of cellulase-free xylanase by alkalophilic Bacillus subtilis and its application in biobleaching of kraft pulp. Biores. 4, 1109-1129.

Santos, K.C., Cassimiro, D.M.J., Avelar, M.H.M., Hirata, D.B., De Castro, H.F., Fernàdez Lafuente, R. and Mendes, A.A. 2013. Characterization of catalytic properties of lipase from plant seed for the production of concentrated fatty acids from different 
vegetable oils. Industrial Crops and Products, 49, 462-470.

Sepahy, A. A., Ghazi, S. and Akhavan, S. M. 2011. Cost-Effective Production and Optimization of Alkaline Xylanase by Indigenous Bacillus mojavensis AG137 Fermented on Agricultural Waste. Enz. Res. 593-624.

Shanab, S. M. M., Shalaby, E. A., Lightfoot, D. A., ElShemy, H. A. 2010. Allelopathic effects of water hyacinth (Eichhornia crassipes). PLoS One. 5(10), e13200.

Shirling, E.B. and Gottlieb, D. 1966. Methods for characterization of Streptomyces species. International J. System. Evolution. Microbiol. 16(3), 313-40.

Sivaramakrishnan, S. and Gangadharan, D. 2009. Edible Oil Cakes. In: Nigam P.S., Pandey A. (eds) Biotechnology for Agro-Industrial Residues Utilisation. Heidelberg: Springer.

Solanki, R. M., Khanna and Lal, R. 2008. Bioactive compounds from marine actinomycetes. Ind. J.Microbiol. 48,
410-431.

Teather, R.M. and Wood, P.J. 1998. Use of Congo red-polysaccharide interactions in enumeration and characterization of cellulolytic bacteria from the bovine rumen. Appl. Environ. Microbiol. 43, 777-780.

Techapun, C., Poosaran, N., Watanabe, M. and Sasaki, K. 2003. Optimization of aeration and agitation rates to improve cellulose-free xylanase production by thermotolerant Streptomyces sp. Ab106 and repeated fed-batch cultivation using agricultural waste. J. Biosc. Bioenginn. 95, 298-301.

Umsza-Guez, M. A., Díaz, A. B., de Ory, I., Blandino, A., Gomes, E. and Caro, I. 2011. Xylanase production by Aspergillus awamori under solid state fermentation conditions on tomato pomace. Braz. J. Microbiol. 42(4), 1585-1597. DOI: $10.1590 / \mathrm{S} 1517$ 838220110004000046 .

\section{How to cite this article:}

Emilda Rosmine, Neethu Changan Edassery Sainjan, Reshma Silvester and Saramma Aikkarakunnath Varghese. 2019. Utilisation of Agrowaste Xylan for the Production of Industrially Important Enzyme Xylanase from Aquatic Streptomyces sp. and Potential Role of Xylanase in Deinking of Newsprint. Int.J.Curr.Microbiol.App.Sci. 8(01): 2061-2076. doi: https://doi.org/10.20546/ijcmas.2019.801.216 